\title{
La infografía digital periodística y su aporte a la prensa escolar ${ }^{\star}$
}

\begin{abstract}
Resumen
Esta investigación indaga por el aporte de la infografía digital periodística a la prensa escolar. Se realizó a través de revisión bibliográfica y entrevistas semiestructuradas con infógrafos de tres medios periodísticos, docentes y estudiantes de grados $8^{\circ}$ y $9^{\circ}$ de bachillerato en tres colegios en Medellín, Colombia. El estudio reflejó que la infografía periodística es propicia para ser usada en la prensa escolar porque tiene características que promueven el aprendizaje, especialmente para las nuevas generaciones; además, se encontró que los equipos de infografía reconocen avances y retos en producción, gestión y publicación de contenidos, y que en los colegios existe la necesidad de actualizar la prensa escolar a través de las TIC, para lograr mayor impacto educativo. En este sentido, la infografía periodística es un recurso adecuado como herramienta digital, que facilita la apropiación social del conocimiento, gracias a las plataformas virtuales que pueden ser aprovechadas por la escuela.
\end{abstract}

\footnotetext{
"Título: La Infografía Digital Interactiva, en tanto recurso periodístico, como apoyo al proceso educativo para la producción y divulgación de contenidos en la prensa escolar, en dos instituciones oficiales y una privada en Medellín entre 2016 y 2017: instituciones educativas Alfonso Upegüi Orozco e INEM José Félix de Restrepo (Oficiales) y Colegio Salesiano E Sufragio (Privado). Sitio que acompaña al artículo: https://2017informagrafia.wixsite.com/udea
}

\author{
Maritza Ruiz Ramírez \\ Maestría en Comunicaciones \\ Licenciada en Educación Primaria y \\ Comunicadora Social-Periodista \\ Universidad de Antioquia, Medellín \\ Correo electrónico: \\ mruiz812@gmail.com \\ ำ orcid.org/0000-0002-3205-8018 \\ Google Scholar
}

Recibido: agosto 29 de 2018 Aprobado: julio 12 de 2019

Palabras clave:

Infografía periodística, interactividad, periodismo digital, prensa escolar, TIC. 


\section{The journalistic digital infographic and its contribution to the school press}

\begin{abstract}
This research inquiries into the contribution of digital newspaper infographics to the school press. It was carried out through bibliographic review and semi-structured interviews with infographic designers of three journalistic media, and teachers and of 8th and 9th grade students in three high schools in Medellín, Colombia. The study showed that journalistic infographic is favorable to be used in the school press because of its characteristics that promote learning especially for the new generations. In addition, it was found that infographic teams recognize advances and challenges in content production, management and publication and that there is a need to update the school press through ICTs to achieve greater educational impact. In this sense, journalistic infographics are a suitable resource as a digital tool that facilitates the social appropriation of knowledge thanks to the virtual platforms that can be used by the school.
\end{abstract}

Key words:

Communication technologies, digital journalism, information, interactivity, journalist infographics, school press. 


\section{Introducción}

La educación básica y media requiere actualizar el aprendizaje y la interacción, mediante interrelaciones entre comunicación digital, periodismo, tecnología y educación, y Tecnologías de la Información y las Comunicaciones (TIC), desde la prensa digital y la infografía como contenidos cotidianos y gratuitos. Así, la prensa puede ayudar a los colegios a conectar cotidianidad y misión formadora. Castrillo (2009), periodista del diario El Mundo (España), plantea que se debe formar a partir de la prensa, pues esta y la educación "pretenden enseñar, informar y, sobre todo, formar ciudadanos libres que conocen su entorno, el tiempo que les ha tocado vivir y los antecedentes de ese momento histórico" (p. 61). De igual modo, González en un trabajo académico afirma "las noticias de cada día son una gran fuente pedagógica que convierte el aprendizaje en competencial y significativo" (2016, p. 21).

La relación prensa y escuela tiene historia. El New York Times, de Estados Unidos, fue pionero con programas de Prensa Escuela, en 1932. En Iberoamérica, desde 1980, periódicos como La Voz de Galicia (España), Clarín (Argentina), Hoy (Ecuador), y El Comercio (Perú) promovieron iniciativas similares. En España, El País desarrolla El País de los estudiantes desde 2001, apoyando a periódicos escolares y comunidades virtuales. En Colombia, Prensa Escuela inició en 1993 con un convenio entre Ministerio de Educación Nacional (MEN), Organización de Estados Iberoamericanos (OEI) para la Educación, la Ciencia y la Cultura, y Asociación Colombiana de Medios de Información (AMI - antes Andiarios) con 15 casas editoriales, y aunque este convenio finalizó en 1998, varios medios continuaron.

En Medellín, entre 2002 y 2004, El Tiempo, con apoyo de la alcaldía, trabajó con varias instituciones oficiales para el medio escolar, bajo el programa Escuela Electrónica que "enfocó su trabajo en dos áreas: acompañamiento 
en la producción de periódicos escolares impresos y digitales, orientados por periodistas y las tutorías en los colegios dirigidas por profesionales de la comunicación quienes acompañaron a profesores y estudiantes en la producción de sus medios de comunicación escolar, ya fueran impresos o digitales" (Ceballos, 2015, pp. 28-29). El Mundo vincula a las oficiales al programa Educar Mientras se Informa, desde 2002 para crear el impreso, y El Colombiano acompaña a oficiales y a privadas. Además, la Secretaría de Educación realizó entre 2014 y 2015 un programa de jornada complementaria para medios escolares oficiales.

Hoy la prensa desarrolla formatos hipertextuales e hipermediales, convergencia de recursos y plataformas, además, se reinventa, compite por inmediatez, expansión y contenidos diferenciadores. Allí, la infografía periodística cobra fuerza, pues el acceso virtual a medios cruza la representación gráfica informativa, el periodismo y la visualización, donde los géneros periodísticos pueden ser filtro de contenidos útiles en educación. Por eso, el artículo se centra en infografía digital periodística y aporta a la alfabetización digital e informacional, desde multimedialidad y aprendizaje visual (Marín, 2009).

Se revisó literatura especializada en periodismo digital, infografía periodística y prensa escolar; hallando producciones de comunicadores-periodistas, diseñadores y docentes universitarios, y trabajos específicos sobre infografía periodística y visualización y su aplicación en libros de ciencias naturales, tecnología, educación física y comunicación política. Las producciones cercanas al estudio son: Minervini (2005), Marín (2009), Reinhardt (2008), Aguirre, Menjívar y Morales (2015), Trespalacios (2015) y Rincón (2016).

Minervini (2005) revisó los infográficos como herramienta de acceso y apropiación del conocimiento en biología, su alcance para planear y desarrollar temáticas complejas y evaluar aprendizajes con la imagen, y creó una multimedia para docentes. 
Reinhardt (2008) destacó el valor infográfico, diseño informativo y educación visual para la diversidad cultural, donde la infografía se relaciona con pedagogía, comunicación, psicología cognitiva y semiología, y ofrece lecturas no lineales, fortaleciendo procesos cognitivos y pensamiento complejo, para los retos escolares.

Para Marín (2009), la infografía desde lo comunicacional conversa con lo educativo, con un rol atractivo, efectivo e interesante en periodismo digital, ante convergencia de relatos, redacción y producción, y con múltiples posibilidades didácticas para infografías que contribuyen a un modelo para transferencia de conocimientos, por lo cual, como género periodístico es funcional en educación.

Aguirre, Menjívar y Morales (2015) reconocieron que la infografía, como recurso didáctico en educación, facilita la transmisión informativa y competencias siglo XXI: comunicativa (hablar, leer, escribir y escuchar), informática (búsqueda, selección y organización informativa), multimodal (formas de representación) y digital (trabajo con software), que suponen retos educativos de formar mediante la imagen.

Trespalacios (2015) encontró que, en comunicación política, infografías y visualización de datos están para explorar por su potencial comunicativo, interacción, tipologías, funcionalidad y estética. Además, son piezas útiles en educación política y cívica ante el mínimo interés ciudadano, aportan análisis y participación.

Rincón (2016), desde educación física, resaltó la infografía como apoyo didáctico. Empleó el periódico El Colombiano para contenidos teóricos, actitudinales y procedimentales, y promovió la creación infográfica. 
Estos antecedentes indican que la infografía digital periodística es un campo para investigar, desde su evolución, aplicabilidad y renovación de contenidos en prensa escolar, más allá de la noticia como el género más empleado, porque pese a iniciativas para usar infografía en secundaria, faltan investigaciones sobre empleos institucionales en prensa escolar.

Así, el estudio tiene como objetivo general, explorar el potencial de la infografía digital interactiva, como recurso periodístico, para apoyar producción propia y divulgación de contenidos en prensa escolar de básica y media; y como específicos: estudiar la infografía desde sus realizadores en dos periódicos nacionales (El Colombiano y El Tiempo) y uno internacional (El País, España), y recoger puntos de vista de docentes y estudiantes de tres instituciones con prensa escolar en Medellín. Y, por último, proponer un recurso digital para que docentes y estudiantes aprovechen la infografía y la prensa escolar, integrando diseño, producción y cursos (https://bit.ly/2SObaHW).

El estudio tuvo cuatro etapas: primera, rastreo bibliográfico sobre infografía digital periodística y usos en prensa escolar. Segunda, creación del marco contextual bajo tres elementos: como recurso periodístico, desde lo digitalinteractivo, y en educación; además, definición de diez categorías de análisis. Tercera, entrevistas semiestructuradas con infógrafos de periódicos seleccionados, y con docentes y estudiantes (grupos focales) de tres colegios, y análisis infográfico de los tres periódicos. Cuarta, resultados en ejes temáticos globales (infografía y periodismo; divulgación y audiencias; infografía, prensa y formación escolar), más conclusiones sobre educación, periodismo, equipos de prensa escolar y recomendaciones. 


\section{Referentes conceptuales}

La infografía en prensa digital es un recurso periodístico de tradición, aunque parezca nuevo. Su evolución tiene antecedentes desde arte rupestre, pictogramas, cartografía, ilustración, grabados, estadísticas, mapas climáticos, hasta el inicio en el periódico inglés Daily Post (1740). Sin embargo, a comienzos del siglo XX se ampliaron los infográficos periodísticos con planos, catástrofes, guerras, investigaciones militares y científicas, etc. A partir de 1980, esa infografía se transformó con la informática e internet y se expandió por eventos importantes como la Guerra del Golfo Pérsico (1990-1991), ante dificultades para transmisión directa; y los Juegos Olímpicos en Barcelona, España (1992), porque los anteriores fueron en Estados Unidos (1984) y Corea (1988), bajo otros idiomas. Igualmente, en Colombia ha avanzado la infografía con asuntos relevantes como catástrofes, conflicto armado, proceso de paz, etc.

En general, la infografía está presente en prensa, televisión, internet, libros y artículos científicos; informes empresariales y estatales, redes sociales; museos y centros de aprendizaje interactivo; mapas, tablas, gráficos, diagramas y megainfografías. No obstante, Leturia (1998), Colle (2004), Valero (1999), Marín (2009) y Cairo (2011), entre otros, han construido varias tipologías, dado que la infografía no es una, reviste complejidad y riqueza en posibilidades temáticas.

Para Leturia (1998), hay cuatro categorías: gráficos, mapas, tablas y diagramas, y pueden combinarse. Colle (2004) identifica tres tipos: científicos o técnicos, libros científicos y manuales; de divulgación, enciclopedias, libros, catálogos, publicidad, informes, etc.; y noticiosos o periodísticos. Según Cairo (2011), por composición es descriptiva, objetos, personas o historias; secuencial, pasos y etapas; estadística, métricas, tendencias, etc.; y geográfica, geoposicionamiento. 
Y por finalidad es periodística, científica-didáctica (publicaciones y manuales técnicos) y empresarial (comercial y comunicación interna). Valero (1999) identifica en infografía impresa dos categorías: individuales, con única infografía y tema, y subclases: comparativas, documentales, escénicas y ubicativas; y colectivas, con piezas asociadas a la central, importante como conjunto y con derivaciones. Marín (2009) reconoce que, por su evolución, clasificar a la infografía digital es complejo, toma como referencia a Valero, y propone otras categorías, entre ellas una mixta, donde las infografías comparten características de las cuatro subclases del tipo individual.

Las infografías analizadas fueron individuales o de único tema, aproximándose a comparativas: confrontan datos, paralelos, etc.; escénicas: describen sucesos, lugares u objetos; ubicativas: localización del suceso; y documentales: enfatizan en ciencias, historia, medicina, etc., con aporte informativo y educativo.

Sobre funciones comunicativas infográficas, para Valero y Marín, esta amplía, compara, comunica, documenta, recrea y ubica, y una pieza puede reunir varias funciones. Para Cairo, hay funciones como mostrar, comparar, clasificar y correlacionar, en pro de objetividad, precisión y eficacia, y afirma que la función restringe la forma, y no al contrario, así que la infografía es un arte funcional, no desde perfección, si no posibilidades de representación.

Un segundo referente conceptual es la infografía digital interactiva, como parte de prensa digital con algunas características naturales. Por ejemplo, entre las cuatro etapas evolutivas de cibermedios en Latinoamérica (1995-2005), en el estudio de Rost (2006), la infografía digital está en la de interactividad, entre presencia corporativa, volcado impreso a digital, contenidos propios y actualizados, e interactividad. Esta última es selectiva (selección de contenidos) y comunicativa (expresión y comunicación a partir del medio), e incluye reportajes multimedia, directos, infografías, etc., con participación y visibilidad 
del usuario. Rost plantea seis elementos del periodismo digital conectados con infografía: interactividad, hipertextualidad, multimedialidad, documentación ilimitada o universalidad, actualidad múltiple y personalización. La infografía también cumple con cuatro leyes sobre los medios, de Marshall y Enric McLuhan, y referenciadas por Marín (2009) aplicadas a infografía (Tabla 1).

Tabla 1. Leyes de los medios en infografía.

\begin{tabular}{ll}
\hline Leyes & La infografía \\
\hline Caducidad & $\begin{array}{l}\text { Aporta a captura, procesamiento y articulación de información visual, reduciendo } \\
\text { captación textual }\end{array}$ \\
\hline Extensión & Extiende conocimiento y análisis visual, relacionado con texto o sonido \\
\hline Reversión & Apoya convergencia y transformación mediática, resaltando lo mejor \\
\hline Recuperación & $\begin{array}{l}\text { Recupera la imagen más simple hasta diversificarla: animaciones, 3D, simulaciones, } \\
\text { etc. }\end{array}$ \\
\hline
\end{tabular}

Fuente: elaboración propia basada en Marín (2009).

La Tabla 2 presenta características de la infografía digital de Marín (2009) y Valero (1999), reconocidos académicos iberoamericanos del área. 
Tabla 2. Características de infografía digital.

\begin{tabular}{|c|c|c|}
\hline \multirow{6}{*}{ Marín } & Hipertextualidad & $\begin{array}{l}\text { En enlaces, botones y redes sociales, se explora y profundizan } \\
\text { contenidos asociados. }\end{array}$ \\
\hline & Multimedialidad & $\begin{array}{l}\text { Reunión de recursos complementarios o únicos, pero no } \\
\text { redundantes. }\end{array}$ \\
\hline & Instantaneidad & $\begin{array}{l}\text { Contenidos actualizados en tiempo real a diferencia de infografía } \\
\text { impresa. }\end{array}$ \\
\hline & Universalidad & $\begin{array}{l}\text { Iconicidad, gráficos y elementos visuales fácilmente comprendidos } \\
\text { en diferentes geografías. }\end{array}$ \\
\hline & Personalización & $\begin{array}{l}\text { Posibilidad de almacenar, descargar, preferir, comentar, compartir y } \\
\text { disfrutar lo responsive. }\end{array}$ \\
\hline & Interactividad & $\begin{array}{l}\text { Fácil movimiento en recorridos internos y externos de la pieza y } \\
\text { personalización informativa. }\end{array}$ \\
\hline \multirow{11}{*}{ Valero } & Utilidad & $\begin{array}{l}\text { Contenidos significativos, más allá de noticias de última hora: } \\
\text { utilidad y atemporalidad. }\end{array}$ \\
\hline & Información & $\begin{array}{l}\text { El lead o párrafo principal responde preguntas periodísticas: ¿qué o } \\
\text { quién?, ¿cuándo?, ¿dónde?, ¿cómo y/o por qué? }\end{array}$ \\
\hline & Significación & Analizar si la infografía es complemento o accesorio textual. \\
\hline & Funcionalidad & Nuevos elementos para facilitar comprensión, sin duplicaciones. \\
\hline & Concordancia & Con la temática, noticia, hecho, comprensión general, etc. \\
\hline & Visualidad & Pieza comprensible y responsive. \\
\hline & $\begin{array}{l}\text { Movimiento } \\
\text { (Cinética) }\end{array}$ & $\begin{array}{l}\text { Navegación con sensación de movilidad en recorrido visual: } \\
\text { diferentes sentidos, siguiendo flechas, scroll, zoom, etc. }\end{array}$ \\
\hline & Comprensión & $\begin{array}{l}\text { Contenido reconocible, sencillo y universal, sin información } \\
\text { adicional. }\end{array}$ \\
\hline & Iconicidad & $\begin{array}{l}\text { Comprensión fácil con íconos, imágenes figurativas, dibujos con } \\
\text { contornos y fotos. }\end{array}$ \\
\hline & Tipografía & $\begin{array}{l}\text { Incluye título, fuentes, créditos, pie de foto, textos como enlace } \\
\text { o divisores de componentes infográficos, y en rótulos o mapas: } \\
\text { palabras clave. }\end{array}$ \\
\hline & Estética & $\begin{array}{l}\text { Aunque el diseño informativo facilita infografías estéticamente } \\
\text { interesantes, el infógrafo prioriza: veracidad, concisión y } \\
\text { coherencia. }\end{array}$ \\
\hline
\end{tabular}

Fuente: elaboración propia basada en Marín (2009, pp. 286-289) y Valero (1999). 
Aquí no se abordan todas estas propiedades, sí transversalmente y se enfatiza en interactividad. Para Marín, esta permite al usuario decidir recorridos y personalizar contenido; para Díaz (2006), ayuda a intervenir eficazmente el discurso hipertextual, interfaces y entornos colaborativos; y para Cairo (2008), facilita relación usuarios-objetos desde visibilidad, retroalimentación, pistas de uso y restricciones. Díaz (2006), la referencia como: técnica (conexión usuario-sistema informático) y relacional entre individuos (personalización informativa, seguimiento de orden, jerarquización, tiempo de actualización, preferencias del usuario).

Por su parte, frente a infografía e interactividad, Moreno (citado por Marín, 2009) y Trespalacios (2015) retomando a Rost (2006) la segmentan en niveles. Moreno, en nivel 0 , sistemas lineales o fijos; nivel 1 , acceso lineal con opciones para avanzar, retroceder y pausar; nivel 2, avance semilineal; nivel 3, acceso aleatorio a contenidos; y nivel 4 , funcionamiento en red con enlaces externos. Y Trespalacios (2015) presenta la interactividad selectiva en nivel 0 (imágenes): infografías estáticas; nivel 1 (lineales): con botones de retroceso y avance; nivel 2 (estructuras de navegación): con enlaces o puntos de navegación; nivel 3 (dinámicas): para ingresar y organizar datos, y nivel 4: fácil acceso a datos. También refiere la interactividad comunicativa para descargar, imprimir, compartir, contactar al autor, etc.

De otro lado, así como la relación prensa, educación y prensa escuela tiene trayectoria, al conceptualizar sobre infografía, se reflexiona su naturaleza como género periodístico, dado que, los géneros informativos ofrecen actualidad, lenguaje directo y objetivo, y se analiza como recurso autónomo, complementario, en relación con otros, etc. Al respecto, Salaverría y Cores (2005) reconocen que los géneros clásicos (noticia, entrevista, etc.) son modelos de creación literaria con función social y doble papel: el periodista estructura información eficazmente, y el lector recibe como modelos de interpretación y 
expectativas, que conducen a posturas frente al contenido. Para Abreu (2002), aunque la infografía acompañe un escrito, es unidad informativa suficiente para comprender sin apoyo, es género con estructura clara, finalidad y sentido propio. Para Valero (2010), si la infografía sustituye o es alternativa al texto, es género. Bárcenas (2012) admite que la infografía es género con lenguaje visual, articulando componentes textuales, gráficos y discursos. Y García (2014) respalda la infografía como género informativo para transmisión eficaz, sin exclusividad textual, "Show, don't tell" / "No lo cuentes; muéstralo".

Las perspectivas académicas citadas, entre otras, sugieren que la infografía es género periodístico, con esencia gráfica, estructurada y completa, informativa y que responde a $5 \mathbf{W}+1 \mathbf{H}$ clásicas del periodismo (what, who, where, why, when y how).

El tercer elemento conceptual es Infografía en la educación, porque la prensa en formación escolar, lectura, alfabetización digital y otros asuntos genera reflexión de pedagogos, periodistas y organismos como la World Association of Newspapers (WAN-IFRA) y la Sociedad Interamericana de Prensa (SIP). Así mismo, periodistas como Valero (1999), sobre las características cualitativas de la infografía, Tabla 2, agrega a las $5 \mathrm{~W}$ la H (how), porque la infografía pregunta ¿cómo o por qué? de los hechos, para que el usuario cuestione a la pieza y determine si responde lingüística o icónicamente. Si es icónica, adquiere valor didáctico para comprensión, al responder más allá de lo textual, ampliar información y hallar elementos no evidentes.

Respecto a infografía en educación, en Prensa Escuela hay un caso relevante en Suramérica: en el 2000, el periódico El Comercio (Perú), con su programa corresponsales escolares, identificó que los docentes coleccionaban sus infografías como material educativo, así que el diario realizó una exposición itinerante en instituciones, con piezas gran formato y temáticas peruanas y 
generales, módulo explicativo, folleto y manual pedagógico, bajo el liderazgo del periodista e infógrafo español Xabier Díaz de Cerio, Jefe Infográfico. Díaz afirma que, dada la premura del impreso, algunas infografías tienen fallas, pero su utilidad trasciende para docentes (Entrevista personal, abril 11 de 2017).

Ante la democratización informativa y cantidad de datos "en bruto", son necesarios filtros como la infografía, en tanto extensión general de cognición, memoria y aprendizajes. Por esto, la relación prensa escolar e infografía está para profundizarse, por ejemplo, bajo la taxonomía del aprendizaje. Para Bloom, esta se divide en tres dominios: cognitivo, afectivo y psicomotor, habilidades de pensamiento y objetivos; y por eso, la versión actualizada por Churches (2008) para la época digital, reconoce a este recurso y a las TIC para recordar, comprender, aplicar, analizar, evaluar y crear, trabajo colaborativo, profundización y conocimiento construido.

En general, la infografía tiene actualidad y trayectoria; antecedentes de formas primitivas de representación gráfica, y carácter novedoso con TIC y aplicación multidisciplinar, lo que hace que, pese a voces autorizadas que argumentan que es género con estructura y sentido propio, y que se produzca esa infografía, exista como apoyo textual, no es "bueno ni malo, positivo o negativo", es parte de su evolución.

\section{Método (instrumentos)}

La metodología es cualitativa, tipo explicativa, como aproximación a asuntos actuales y en construcción, donde académicos como íñiguez (2008) destacan este enfoque para fenómenos sociales cambiantes como los mediáticos. Los instrumentos fueron construidos con miras a experiencias escalables para educación, con entrevistas semiestructuradas individuales (profesionales de infografía, Comunicación, Periodismo, y docentes de instituciones) y grupales 
(estudiantes de secundaria), para aproximarse a la vivencia social dinámica; para orientarse con flexibilidad y cercanía, y construir significados conjuntamente (Hernández, Fernández \& Baptista, 2014; Strauss \& Corbin, 2002).

Hubo varios componentes: revisión bibliográfica sobre infografía periodística, periodismo digital y prensa escolar; selección de tres instituciones con prensa, y tres periódicos de reconocida infografía; definición de ejes temáticos y categorías de análisis de piezas seleccionadas; diálogo con profesionales, docentes y grupos focales; sistematización y resultados. La infografía de El País, El Colombiano y El Tiempo ${ }^{1}$, representa migración digital, evolución, reconocimiento y premios. Inicialmente se escogieron 150 infografías (50 por medio) usando dos rúbricas. La primera incluía criterios como título, noticia asociada, fecha de publicación, sección, infógrafo, etiqueta de pieza o noticia, etc. Luego, se eligieron 15 (5 por medio), de cultura general y atemporales. La segunda rúbrica definió proximidad al usuario, universalidad, intención educativa, continuidad temática, estructura, principios periodísticos, herramientas visuales, tiempo promedio de lectura, dependencia de noticia o especial, usabilidad, interacción, etc. Se analizaron 15 piezas con infógrafos y profesionales afines; y 9 con docentes y estudiantes. La Tabla 3 contiene piezas revisadas con infógrafos y profesionales; y con docentes y estudiantes. (*)

' Sitio web con periódicos e infografías disponibles. https://bit.ly/2SObaHW 
Tabla 3. Infografías analizadas.

\begin{tabular}{lll}
\hline \multicolumn{1}{c}{ EL COLOMBIANO } & \multicolumn{1}{c}{ EL TIEMPO } & \multicolumn{1}{c}{ EL PAís } \\
\hline $\begin{array}{l}\left(^{*}\right) \text { 64 años después: hora de } \\
\text { abordar el Tranvía }\end{array}$ & Así se llevan nuestro pasado & $\begin{array}{l}\text { Espacio Eco ¿Qué país produce } \\
\text { más basura? }\end{array}$ \\
\hline $\begin{array}{l}\left(^{*}\right) \text { Así funciona el sistema de } \\
\text { alerta temprana (Siata) }\end{array}$ & $\begin{array}{l}(*) \text { El Istmo de Panamá, "El } \\
\text { accidente geográfico se } \\
\text { amplía" }\end{array}$ & $\begin{array}{l}\left({ }^{*}\right) \text { Planeta Futuro: Regreso a la } \\
\text { infancia }\end{array}$ \\
\hline $\begin{array}{l}\text { Antioqueños, ahorrar energía es } \\
\text { fácil }\end{array}$ & $\begin{array}{l}(*) \text { El costo ambiental de la } \\
\text { ropa que está en su armario }\end{array}$ & $\begin{array}{l}\left({ }^{*}\right) \text { Dolly: dos décadas de la } \\
\text { clonación del primer mamífero }\end{array}$ \\
\hline $\begin{array}{l}\text { Perros y bozales pueden llevarse } \\
\text { bien }\end{array}$ & $\begin{array}{l}\text { ¿Qué es el internet de las } \\
\text { cosas? }\end{array}$ & $\begin{array}{l}(*) \text { Terremotos- Así se produce un } \\
\text { terremoto }\end{array}$ \\
\hline $\begin{array}{l}\left(^{*}\right) \text { Amenaza de movimientos } \\
\text { telúricos en el país }\end{array}$ & $\begin{array}{l}(*) \text { ¿Dónde están los billetes } \\
\text { que ya no usamos? }\end{array}$ & $\begin{array}{l}\text { Proceso de paz en Colombia- } \\
\text { El conflicto entre el Gobierno de } \\
\text { Colombia y las FARC }\end{array}$ \\
\hline
\end{tabular}

Fuente: Elaboración propia.

Fueron 16 entrevistas individuales, con tres clasificaciones: directores de equipo e infografistas de tres periódicos; profesionales de infografía, medios, universidades y colegios (comunicadores, periodistas, diseñadores), y docentes en instituciones de muestra ${ }^{2}$. Por entrevista se dispuso una guía: infógrafos y profesionales: definición de infografía; infografía y periodismo; infografía de muestra; retos y futuro del género; interactividad e infografía; prensa, infografía y educación. Docentes: definición de infografía; experiencia con prensa; infografía e interactividad; aplicabilidad institucional; infografía, prensa y formación escolar, en la Tabla 4 se detalla. 
Tabla 4. Participantes entrevistas.

\section{GRUPO 1}

\begin{tabular}{l}
$\begin{array}{c}\text { El Colombiano - Ricardo Ramírez - Editor-Infografista Departamento de Infografía } \\
\text { Jaime Trujillo - Periodista-Infografista }\end{array}$ \\
\hline El Tiempo Digital - Alejandro Urueña- Jefe Visualización de Datos + Infografía Digital \\
\hline El Tiempo Impreso -Juan Pablo Noriega - Jefe Infografía CEET \\
\hline El País - Rodrigo Silva-Subjefe Infografía e Ilustración \\
\hline Ignacio Catalán- Periodista-Infografista \\
\hline Yolanda Clemente - Periodista-Infografista \\
\hline Marcela Madrid - Comunicadora Social- Periodista y docente - Colombia \\
\hline Marcela Castaño -Diseñadora Visual y docente - Colombia \\
\hline Evaristo González- Periodista y docente - Investigador Comunicación y Educación- España \\
\hline Xabier Díaz de Cerio- Periodista-Infografista español (Perú) \\
\hline GRUPO 3 \\
\hline Astrid Arregocés- IE INEM José Félix de Restrepo \\
\hline Teresa Gómez- Colegio Salesiano El Sufragio \\
\hline Mary Luz Rendón -Colegio Salesiano El Sufragio \\
\hline Fuente: Elaboraón propia-
\end{tabular}

Fuente: Elaboración propia.

Al seleccionar instituciones se confirmó que pocas oficiales tienen prensa autogestionada, así que se buscó compromiso institucional, conectividad, y prensa vigente (2014-2016). Participaron tres instituciones (dos oficiales y una privada), cuatro docentes y 24 estudiantes grados $8^{\circ}$ y $\mathbf{9}^{\mathbf{0} 3}$, entre 12-17 años. La Tabla 5 tiene generalidades y el sitio web, detalles.

\footnotetext{
${ }^{3}$ Se eligieron $8^{\circ}-9^{\circ}$ por formación y continuidad escolar; $10^{\circ}-11^{\circ}$ grado tienen poco tiempo libre y están próximos a egresar.
} 
Tabla 5. Instituciones participantes.

\begin{tabular}{|c|c|c|c|}
\hline Institución & Medio-año fundación & $\begin{array}{l}\text { Recurso } \\
\text { publicación }\end{array}$ & Equipo humano \\
\hline $\begin{array}{l}\text { Alfonso Upegüi } \\
\text { Orozco-oficial- } \\
\text { (San Cristóbal) }\end{array}$ & UPO Ciencias (2016) & $\begin{array}{l}\text { Trimestral. Issuu. } \\
\text { com. Área UPO } \\
\text { Ciencias. } 6 \\
\text { ediciones a } 2017 .\end{array}$ & $\begin{array}{l}\text { Proyecto interno entre pares } \\
\text { (diálogo entre áreas). } \\
\text { Apoyan docentes primaria y } \\
\text { secundaria (ciencias naturales, } \\
\text { física y química) y estudiantes. }\end{array}$ \\
\hline $\begin{array}{l}\text { INEM José Félix de } \\
\text { Restrepo-oficial (El } \\
\text { Poblado) }\end{array}$ & El Humanista ${ }^{4}$ (1978) & $\begin{array}{l}\text { Anual. Issuu. } \\
\text { com, y en web } \\
\text { del comité de } \\
\text { publicación. } 61 \\
\text { ediciones a } 2017 .\end{array}$ & $\begin{array}{l}\text { Comité de docentes español y } \\
\text { estudiantes } 10^{\circ}-11^{\circ} \text {. } \\
\text { Apoyo: Especialidad } \\
\text { Humanidades énfasis } \\
\text { Comunicación y Medios. } 10^{\circ}-11^{\circ}\end{array}$ \\
\hline $\begin{array}{l}\text { Colegio Salesiano } \\
\text { El Sufragio } \\
\text { (Boston) }\end{array}$ & La Ventana ${ }^{5}(1977)$ & $\begin{array}{l}\text { Anual. Publitas. } \\
\text { com. } 52 \\
\text { ediciones a } 2016\end{array}$ & $\begin{array}{l}\text { Bibliotecóloga, unidad de } \\
\text { comunicaciones, docentes } \\
\text { de español y estudiantes de } \\
\text { secundaria. }\end{array}$ \\
\hline
\end{tabular}

Fuente: elaboración propia. Nota: La publicación de la IE Alfonso Upegüi es digital (PDF) con algunas URL; y las del INEM y El Sufragio impresas y digitales (PDF).

Se optó por grupos focales con estudiantes, modalidad de entrevista grupal y semiestructurada para identificar conocimientos, experiencias y una aproximación fluida y efectiva, como destaca Aigneren (2002), por cuanto la unidad de análisis es el grupo, expresiones y construcciones abordadas (Hernández et al., 2014). Fueron tres etapas: observación de infografías, ficha individual de preguntas, y socialización. Se seleccionaron infografías 2013$2017^{6}$, y para analizarlas se crearon 10 categorías (Tabla 6).

\footnotetext{
${ }^{4}$ El Humanista: galardón 2016 Mejor Periódico Escolar, Séptimo Premio de Periodismo Comunitario Alcaldía de Medellín. http://bit.ly/2FFdy1C ${ }^{5}$ También tienen sitio web, noticiero en YouTube y Facebook (ver sitio web del estudio).

${ }^{6}$ Período por cercanía con estudiantes; porque las infografías digitales en prensa aparecen desde 2011; para no abordar solo recientes (20162017), y no generar recordación inmediata.
} 
Tabla 6. Categorías de análisis infográfico.

\begin{tabular}{|c|c|}
\hline $\begin{array}{l}\text { 1. Formato: imagen fija (estática) o multimedial } \\
\text { (dinámica) }\end{array}$ & 2. Estructura y flujo de información \\
\hline $\begin{array}{l}\text { Imagen clásica-tradicional: ilustraciones, diagramas, } \\
\text { estadísticas, mapas, etc., y bidimensionales: ancho- } \\
\text { alto. Según Colle (2004), incluyen megainfográficos } \\
\text { o "mega-cuadros", de mayor elaboración, análisis y } \\
\text { complejidad. Imagen multimedial de lenguaje web con } \\
\text { tres dimensiones: ancho, alto y profundidad; y audios, } \\
\text { videos, galerías, animaciones, simulaciones, datos, etc. }\end{array}$ & $\begin{array}{l}\text { Componentes comunes con noticias: título, entradilla, } \\
\text { cuerpo, elementos visuales, créditos; presentación } \\
\text { informativa, amplia o mínima, densa o liviana, general a } \\
\text { particular o viceversa, navegación preestablecida o abierta } \\
\text { con enlaces contextuales o sencillos ( } 5 \mathrm{~W} \text { periodísticas), } \\
\text { relacionales asociados con noticias o infografías; y } \\
\text { recomendados de investigación y profundidad en diario u } \\
\text { otro medio (Fondevila, 2014). }\end{array}$ \\
\hline 3. Autonomía & 4. Temporalidad y continuidad temática \\
\hline $\begin{array}{l}\text { Independencia total de pieza (estado ideal), al ser en } \\
\text { sí misma producto periodístico completo o unidad } \\
\text { informativa independiente, o nivel de dependencia } \\
\text { alcanzado, si es resumen o complemento del contenido } \\
\text { textual, que implica lectura para comprender. }\end{array}$ & $\begin{array}{l}\text { Vigencia temática infográfica por asunto actual pero no } \\
\text { coyuntural, elaborada para la redacción, investigación } \\
\text { autónoma del equipo, o acontecimiento de agenda } \\
\text { específica o anual, y posibilidades de infografías } \\
\text { asociadas. }\end{array}$ \\
\hline 5. Proximidad temática & 6. Universalidad \\
\hline $\begin{array}{l}\text { Nivel de familiaridad o proximidad al usuario con la } \\
\text { pieza según valor temático, tratamiento informativo, } \\
\text { originalidad, novedad o reconocimiento en contexto de } \\
\text { la audiencia. }\end{array}$ & $\begin{array}{l}\text { Grado de iconicidad o representatividad que otorga valor } \\
\text { global a la pieza, opuesto a abstracción. Así, aunque sea } \\
\text { en español, es comprensible por convención para usuarios } \\
\text { internacionales u otras culturas internas. }\end{array}$ \\
\hline 7. Acceso y usabilidad & 8. Interactividad \\
\hline $\begin{array}{l}\text { Nivel de funcionalidad en ingreso libre o con registro } \\
\text { a infografías, al buscador del sitio o a uno interno, por } \\
\text { palabra clave o etiquetas. Movimiento y experiencia } \\
\text { de navegación según interfaz web, que supera impacto } \\
\text { estético y facilita exploración e interacción con pocos } \\
\text { "clics", y aprendizaje. }\end{array}$ & $\begin{array}{l}\text { Rol del usuario en decisiones, ruta de lectura, } \\
\text { personalización, uso del zoom propio o del navegador, } \\
\text { menú desplegable, selector, audio, etc. Se adoptó } \\
\text { propuesta de interactividad por niveles (Tabla 2). }\end{array}$ \\
\hline 9. Movilidad & 10. Aplicabilidad escolar \\
\hline $\begin{array}{l}\text { Diseño adaptable o responsive design: operatividad de la } \\
\text { pieza en conectividad, carga e interacción en dispositivos. } \\
\text { Si es igual impresa y digital, o con diseño centrado en } \\
\text { usuario, interfaz intuitiva y manejable. }\end{array}$ & $\begin{array}{l}\text { Aporte significativo como representación informativa } \\
\text { distinta, que favorece aprendizaje y competencias siglo } \\
\text { XXI. Si la pieza supera lo informativo y actúa como } \\
\text { recurso educativo digital, y propicia creatividad, reflexión } \\
\text { y conversación. }\end{array}$ \\
\hline
\end{tabular}

Fuente: Elaboración propia. 
La metodología comprende sujetos clave: infografistas, docentes y estudiantes, como productores y receptores actuales o potenciales de infografía y alfabetización digital y mediática, ante la revolución tecnológica y educativa. Los docentes experimentan competencias como plantea la UNESCO: entender el papel de los medios y la información en la democracia; comprender el contenido de los medios y sus usos; evaluar críticamente la información y las fuentes; aplicar los formatos nuevos y tradicionales, entre otras (Wilson, Grizzle, Tuazon, Akyempong \& Cheung, 2011).

En estudiantes, las competencias mediáticas han sido descritas entre otros, por Ferrés y Piscitelli (2012), al reunir destrezas, conocimientos y actitudes, bajo seis dimensiones: lenguajes, procesos de interacción, tecnología, producción y difusión, ideologías y valores, y estética. Las describen en dos ámbitos, análisis: competente si interactúa críticamente con mensajes producidos por otros, y expresión, competente al producir y diseminar mensajes propios. Si bien los estudiantes entrevistados son Generación Z, no implica que tengan desarrolladas dichas competencias, por lo que las entrevistas contribuyeron a análisis infográfico e interacción crítica, y para la expresión, el sitio del estudio aporta competencias desde la producción.

\section{Resultados}

Se consolidaron tres áreas: periodismo y creación infográfica; gestión de infografías y comunicación desde equipos periodísticos; y aplicación escolar. Así, la primera: Infografía y periodismo, analiza este recurso, uso con otros géneros, aporte del diseño gráfico y visualización de datos, y enseñanza infográfica en la academia. La segunda Divulgación y audiencias, aborda difusión web y micrositios en medios, redes sociales de equipos infográficos, diseño Responsive y retos con audiencias. Y tercera, Infografía, prensa y formación escolar, para ver la intencionalidad al producirla en los medios analizados, ventajas y oportunidades educativas. 


\section{Infografía y periodismo}

Bajo la Tabla 6, se encontró que el formato de la imagen es tanto fijo-estático como multimedial-dinámico. En El Colombiano y en dos infografías de El Tiempo se detectó formato fijo sin responsive, pese a ser digitales, caso Megainfográficos El Colombiano, determinantes del diseño de páginas. En El Tiempo y El País hubo tendencia al formato multimedial y herramientas webmóviles, adicionales al software habitual, encontrándose mayor flexibilidad en El Tiempo. Frente al Formato, los grupos focales valoraron (por ejemplo, en El Colombiano) la ilustración principal, detalles de diseño, colores, "entorno agradable" y unidad estética; aspectos importantes del impacto de piezas fijas en contextos móviles. Esto remite a la relevancia de imágenes fijas en educación (afiches, libros, enciclopedias, etc.), así que la prensa puede aprovechar esa infografía en distintas versiones. Ello se relaciona con la Ley de recuperación de McLuhan, para revitalizar componentes informativos cuya receptividad disminuye con el tiempo (Tabla 1).

Los equipos infográficos consideraron que la prioridad no es, pieza fija o dinámica, sino contenido, y coindicen en resaltar que diarios españoles como $E l$ Mundo y El País tienen sencillez y claridad como esencia, sin megainfográficos frecuentes, por dificultades temporales para publicación, pocos profesionales, software, etc.

Ante Estructura y Flujo de la información, los infógrafos coincidieron que necesitan igual rigurosidad que en el equipo de redacción, y que aprueban solicitudes de infografía según calidad, estructura y claridad por encima de diseño o "demanda de redacción". Así, tres investigadores colombianos, Vargas, Greiff y Rojas (2014), hablan de infografía como presentación informativa de modo lógico, gráfico y diagramático, evidente en El Colombiano con estructura casi invariable, y otras características que señalan circulación informativa para el usuario; estas infografías son claras, bien diseñadas y equilibradas. 
Sin embargo, en megainfografías se afecta en ocasiones la estructura, al no jerarquizar tipografías, superponer partes al logo del periódico y saturar datos (Imagen 1).

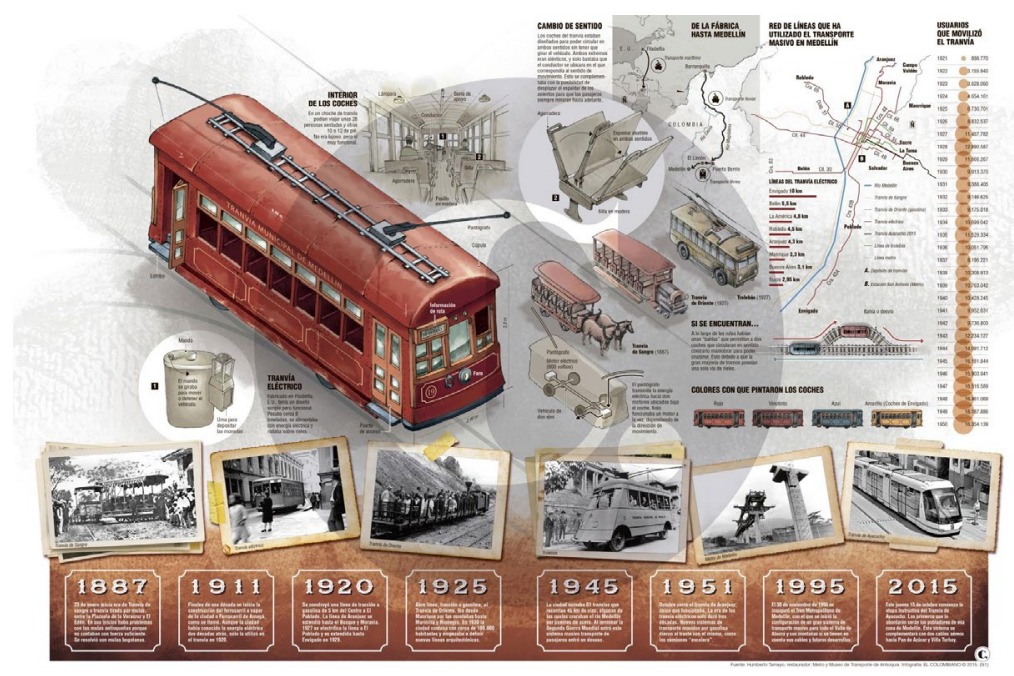

Imagen 1. 64 años después. Hora de abordar el tranvía. El Colombiano.

En estructura y flujo, El Tiempo posee estructura similar a El Colombiano, pero la información fluye entre capas o niveles con posibilidades web (anchura, altura, profundidad); por ello, los estudiantes destacaron en este medio, la distribución "en partes", que genera expectativa, a diferencia de entregas totales "piezas enteras". Los infógrafos y comunicadores entrevistados opinan similar ante la distribución; por ejemplo, la comunicadora y docente Marcela Madrid expresa que "Los accidentes aéreos" (El Tiempo) "es una infografía a nivel de gráfico impecable, bonita y potente" (Entrevista personal, mayo 16 de 2017). El País, para la movilidad, aprovecha bloques independientes y evita sobrecarga 
visual, así en "Regreso a la Infancia" (Imagen 2) hay flujo informativo con hipertextualidad, matizando densidad con enlaces contextuales, relacionales y recomendados (Fondevila, 2014).

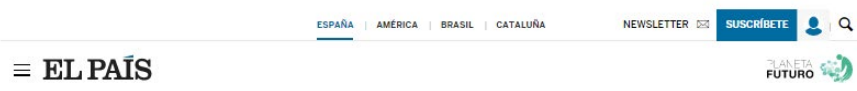

EN PRIMERA LINEA RED DE EXPERTOS QUÉ MUEVEA... DESARROLLO EN AFRICA BLOGS CIUDADES SOSTENBLLES

AVANCE Consulta la portada de EL PAIS, Edcléon Europa, del mlercoles 3 de mayo »

\section{Regreso a la infancia}

'El País Semanal' y Unicef unieron sus fuerzas en 2009 para mostrar, en un número monográfico, un retrato global de la infancia a través de 20 historias de 20 niños en 20 países. Ahora, cinco años después. viajamos para reencontrarnos con cinco de aquellos menores. Esta es la historia de cómo han cambiado sus vidas, aunque el panorama general sigue mostrando que son ellos, los más pequeños y los jóvenes, el colectivo más vulnerable.
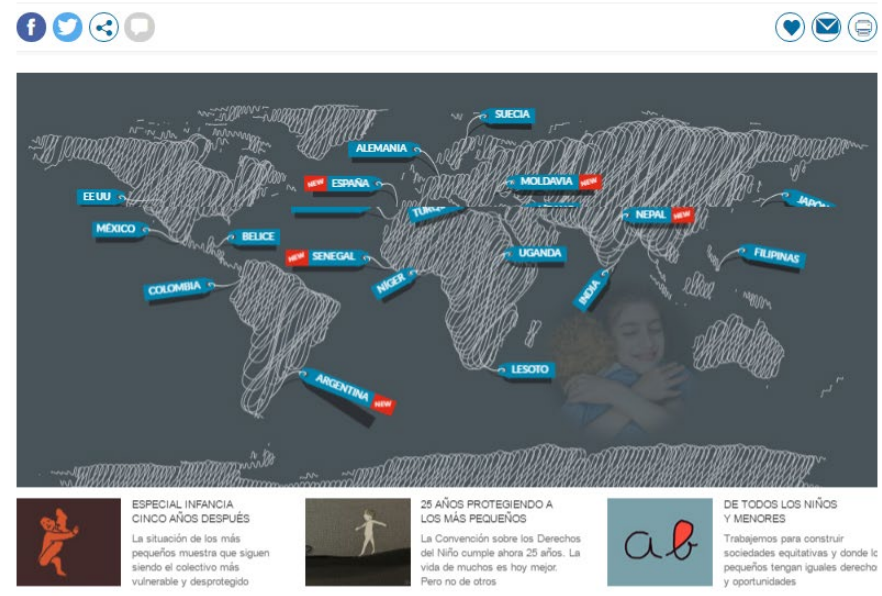

MARIANO ZAFRA $\square$

20 Nov $2014-1712$ COT

$\odot$ ARCHIVADO EN:

berechos nitho - Unicef - Ninos soldado combatientes pobreza - Problemas sociales

- Conflictos - Salud publica - ONU - Poltrica sanitaria - Sanidad - Organizaciones internacionales 
No obstante, tanto en formato fijo como multimedial hay falencias de estructura y flujo informativos: en "¿Qué es el Internet de las cosas?" (El Tiempo) hay carga de flujo (Imagen 3); y en "Costo ambiental de la ropa" (El Tiempo), falta hilo conductor, entradilla, subtítulos y jerarquía; por eso, para los entrevistados, estas infografías parecen "incompletas" y de lectura lineal, falta como plantea García (2014): temporalidad, lecturabilidad y eficacia.

\section{ELTIEMPO \\ $f \quad G+$ \\ El costo ambiental de la ropa que está en su armario}

¿Sabía que para elaborar un kilo de algodón se requieren 11.000 litros de agua, pero usted solo usa el $20 \%$ de toda la ropa que compra? HUELLA SOCIAL le cuenta el panorama en cifras. 02 de marzo de $2017,10: 58 \mathrm{a} . \mathrm{m}$

f G. 0

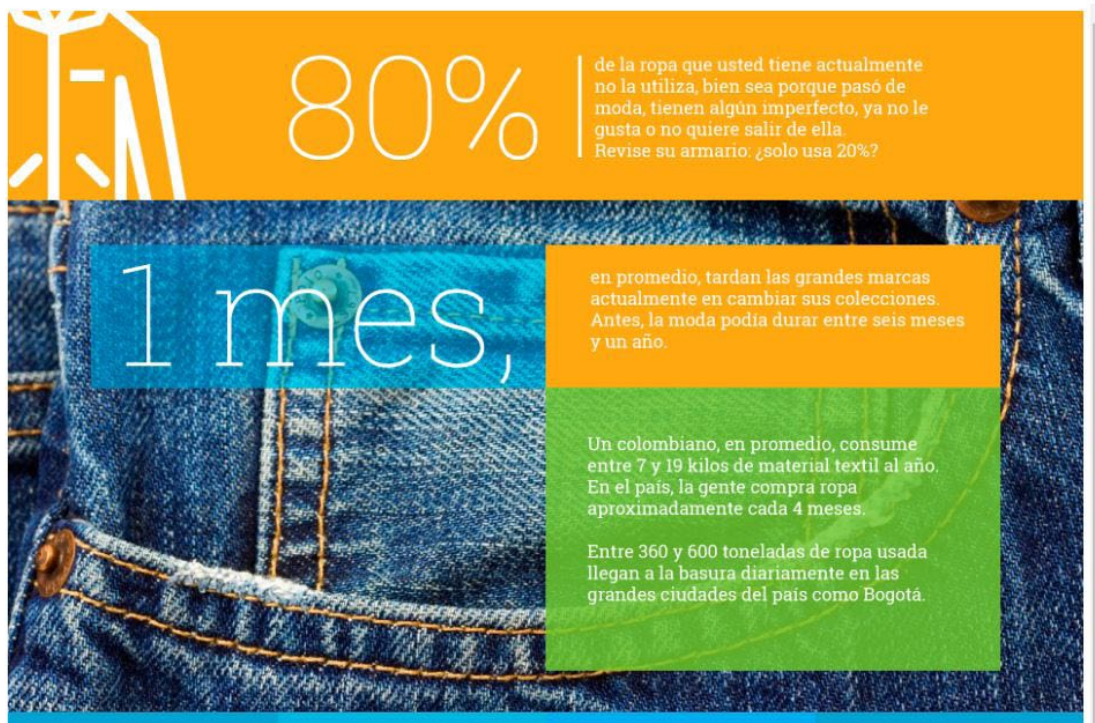

Imagen 3. El costo ambiental de la ropa. El Tiempo. 
La autonomía infográfica es independencia del artículo, evidente en megainfografías de El Colombiano, que, aunque no se publican sin noticias, por elaboración y autonomía podrían ser "producto periodístico completo". Este equipo infográfico afirma que es un género reconocido por la Society for News Design, Capítulo Español (SND-E) y la SIP; reforzando el consenso entre entrevistados sobre infografía periodística, como género que piensa en modos de recepción y multiplataformas.

En El Tiempo, la mayoría de infografías son autónomas y comprensibles. En El País tienen bloques con contexto propio y autonomía, aunque excepciones “¿Qué país produce más basura?” (Imagen 4), con dos gráficos complementarios a un texto cuya lectura parcial es necesaria para comprensión total: ahí no funciona como género, sino como apoyo visual.

Los grupos focales, ante autonomía, opinaron que El Colombiano tenía información suficiente para comprenderse, pero que otras piezas podrían necesitar complementos. En El Tiempo, el "costo ambiental de la ropa" generó inquietudes por falta de subtítulos, conexiones y otras cifras mundiales. Docentes como Teresa Gómez expresaron: "esta pieza es incompleta para entender, tendría que buscar más datos, falta información" (Entrevista personal, mayo 31 de 2017). Astrid Arregocés, afirmó: "ésta parece realizada como noticia textual, y retomaron cifras y apartes para visualizarlos luego, pero no es claro" (Entrevista personal, junio 15 de 2017).

En Temporalidad y continuidad temática, para El País es fundamental que la pieza tenga vida con actualizaciones digitales, y nuevos soportes web-móviles. Sobre temporalidad, entre las seleccionadas se hallaron piezas de actualidad permanente en secciones o contenidos especiales, y otras de actualidad prolongada en tiempo. Por ejemplo, las analizadas presentan generalmente hechos históricos, atemporales y globales y superan temporalidad noticiosa. 
Aun así, se observaron infografías de apoyo a redacción, por lo que, en algunas piezas, las cifras pueden desactualizarse, pero desde lo macro son útiles y educativas, como señalaron docentes y estudiantes. En El País, la denominada "Así se produce un terremoto" aborda temáticas transversales, mundiales y es en Flash (software): "contenido clásico".

ESPACIOECO

\section{¿Qué país produce más basura?}

Localiza en esta infografía las naciones que más residuos generan


RAFA HÖHR | JAIME RIPA

13 OCT 2016- 0514 COT 
Otro tema clave es infografía y su convivencia con otros géneros periodísticos. Así, El Tiempo ha empleado infografía para precisiones en entrevistas, crónicas y opinión. El País considera viable usarla con otros géneros, manteniendo calidad informativa, neutralidad e imparcialidad; pero, en ocasiones, no es fácil separarla de géneros de Opinión. Rodrigo Silva, subdirector de infografía, opina que en El País deben abordarla con neutralidad. También El Colombiano la ha implementado en entrevistas, pero no en Opinión.

Los entrevistados igual analizaron veracidad informativa, apoyada en fuentes periodísticas vivas y no solo documentales; revisión rigurosa, comunicación rápida y completa; y gancho visual para "quedarse" al primer clic, bajo orden de lectura y buena distribución. Igual, los equipos destacaron el valor estético necesario. El Colombiano lo considera un plus si la base de la pieza es informativa, como expresa Ricardo Ramírez, director del equipo: "Hacer un infográfico por la estética es lo peor que puede pasarle a un infografista; la estética, déjela que Ilegue sola" (Entrevista personal, mayo 12 de 2017). También, El Tiempo enfatiza en cuidado y precisión del aporte visual; y en El País priorizan veracidad y claridad periodística con "gancho visual". En concordancia, Cairo (2011) establece que la función de la infografía no es estética por sí misma, sino que la forma se guía por la función: la estética puede ser punto de llegada, pero no finalidad.

En producción profesional con software especializado, al indagar por formación universitaria afín, se encontró que la academia influye en equipos interdisciplinarios de los periódicos, porque no todos son periodistas, hay ingenieros, publicistas, arquitectos. Madrid, como infografista y docente universitaria señala "nos quedamos pensando que el diseño es asunto estético, y con decisiones de diseño priorizas qué querés que la persona lea, cómo lee, un montón de decisiones. Es un arma poderosa de la cual no hacemos uso" (Entrevista personal, mayo 16 de 2017). Finalmente, la infografía no es para 
"observar", sino apropiarse y aprender, y así debe enseñarse y producirse, no es simple impacto visual o estética, sino funcionalidad y vida útil.

Frente a estos primeros resultados, los entrevistados destacan la infografía como género porque, aunque se mueve entre formatos diferentes, se usa junto a otros géneros, y a veces funciona independiente o como apoyo, es fundamental. Por eso, la infografía tiene flexibilidad, avanza con las TIC y no pasa inadvertida entre narrativas digitales.

\section{Divulgación y audiencias}

Frente a difusión infográfica, en ruta de Acceso de las piezas para el usuario, los tres periódicos tienen similitud en espacio virtual de almacenamiento, ubicación en zonas distantes de portada, herramientas de búsqueda, y necesidad de fortalecer gestión de contenidos como equipo infográfico, porque dependen del encargado de redes sociales. Para megainfográficos, El Colombiano tiene micrositio sin filtros, y pese a que las demás imágenes están en el historial del periódico, al filtrarlas por "Infografías", tienen noticia asociada. En El Tiempo, pueden consultarse al digitar palabras alusivas por historial y zonas "Especiales" y "Datos", pero sin filtros. El País tiene sección infográfica (compartida con otros gráficos), igual que en historial general.

En proximidad temática de la infografía para usuarios desligados del lugar del hecho: los grupos focales, destacaron que las piezas presentan cierta terminología desconocida, pero que aplicaron inferencias, lectura contextual, abstracción y saberes previos para comprender. Por ejemplo, en El Colombiano y El Tiempo reconocieron su valor académico y ciudadano con asuntos históricos y actuales. Y en El País encontraron temas de biología, sociales y ética, entre otros; y para eventos institucionales como Feria de la Ciencia. 
Se halló que la universalidad infográfica, favorece divulgación y documentación ilimitada (Rost, 2006): contenidos sin límites espacio-temporales de impacto temático, en oposición al periódico impreso de región específica. Las piezas analizadas tienen representatividad bajo íconos, símbolos y metáforas gráficas cercanas a los escolares, de ahí que grupos focales y docentes valoraran temas para educación, público general y expertos (Imagen 5).

(a) sIsmos

AMENAZA DE MOVIMIENTOS TELÚRICOS EN EL PAÍS

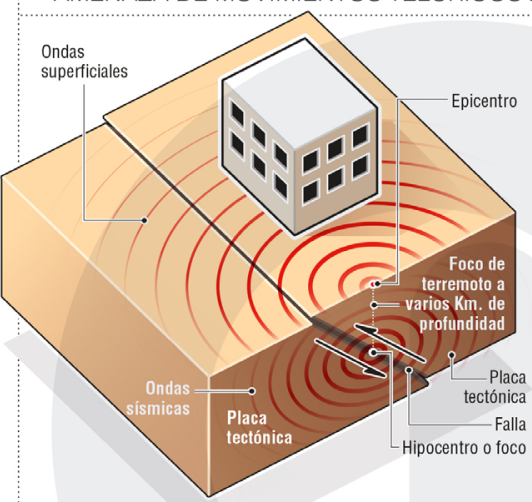

Un movimiento sísmico desencadena una serie iones adicionales que incrementan los niveles de riesgo en la población, como los intos, inundaciones incendios, tsunamis en zonas costeras.

\section{Origen}

1. Las placas sólidas flotan y se desplazan en diferentes direcciones, empujándose con fuerzas enormes.

2. Las fuerzas se van acumulando con el tiempo y en determinado momento produce una ruptura de la roca.

3. Se libera una gran cantidad de energía, la cual se dispersa en ondas, produciendo el movimiento del terreno.

4. Es lo que se conoce como temblor o sismo. Es un movimiento irregular que afecta las construcciones.

\section{Qué hacer en caso de sismos}

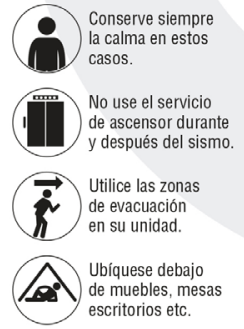
Elimine las fuentes
que puedan provocar
un incendio.



\section{N}

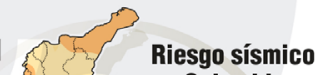

en Colombia Alto

Fuente: Servicio Geológico Colombiano y Unidad Nal. para la Gestión del Riesgo. Infografía: EL COLOMBIANO @ 2016. (N3) 
Respecto a Gestión de la infografía y retos técnicos, profesionales, plataformas, Apps, etc., los equipos infográficos reconocieron posibilidades actuales y necesidades de interacción con audiencias, sobre todo juvenil. El Tiempo valora su audiencia fiel, pero sabe que debe trabajar porque los jóvenes recurren más a redes. Pese a que el equipo de El País tiene sección infográfica y cuentas independientes en Twitter y Facebook, el grupo desearía no compartir esa zona con piezas de otros equipos; además, tener en el home etiquetas o botón hacia el micrositio, automatizar entradas de gráficos, visibilizar la última pieza (actual), y adaptar a Responsive, piezas antiguas.

Ante Usabilidad en infografía, diseño de navegación y arquitectura informativa, efectividad y fácil acceso, las de El Colombiano son imágenes fijas bajo lógica de lectura tradicional; su cuerpo es un "pantallazo" y, en ocasiones, exige al usuario ampliación con lupa propia de la imagen; y su interfaz es esquema de composición "clásico o familiar".

En El Tiempo y El País hay variada representación: al navegar hay puntos que se activan fácil con el mouse encima o clic; y botones con indicaciones: comenzar, flechas adelante/atrás, siguiente, etc.; en general, es diseño claro. Algunos ejemplos incluyen georreferenciación, videos, simulaciones, etc. con Illustrator, Photoshop, Hype, Carto, Tableau, Infogram, Datawrapper, etc.

Sobre rutas de lectura de infografías, Ilamaron la atención en El País: la de "Planeta Futuro" sin orden estricto o predeterminado, mientras que en otras hay camino a recorrer, pauta del infógrafo que es como "plus o guía" para usuarios. Frente a esta pieza, los entrevistados consideraron extenso el tiempo para revisar, pero ingresar con clics en el mapa "tejido" lo estimaron novedoso y navegable. Ante las de El Colombiano y El Tiempo, con mucha información y sin "guías" del infógrafo, los participantes crearon rutas bajo líneas de tiempo, semicírculos y columnas informativas, etc. En Usabilidad e Interactividad, para 
grupos focales y docentes, dos infografías de El Tiempo los cautivaron: "Istmo de Panamá" y "¿Dónde están los billetes que ya no usamos?", por niveles de exploración y botones paso a paso, mientras que el "Costo ambiental de la ropa" de El Tiempo, no fue tan Ilamativa por navegación "lineal". Para Madrid, la pieza de "los billetes" es buen ejemplo de usabilidad: "Importante en esta infografía, la señalización; es clara, sabes a dónde volver, a dónde ir, tienes el paso 1,2; tiene lógica del color, desarrollo gráfico y muy buena navegación".

Dentro de las etapas del periódico digital, en la de Interactividad, la infografía promueve permanencia del usuario y apropiación del contenido. En general, los infógrafos coinciden en que no todas las piezas tienen que ser interactivas, "con movimientos, simulaciones, animaciones, etc." pues dependen de tiempo, información y visualización. Para fomentar interactividad comunicativa, los tres periódicos ofrecen compartirlas en redes y blogs, guardar favoritos, comentar, imprimir, etc. El Colombiano tiene botón AddThis, mientras El Tiempo y El País, compartir en ciertas redes.

En interactividad selectiva hay diferencias entre El Tiempo, El País y El Colombiano, pues este último se caracteriza por estaticidad visual y falta de amplios enlaces a gráficos relacionados; al contrario de El País y El Tiempo, al interactuar con pieza, autor y usuarios, desde lo selectivo y lo comunicativo; y favorecer aprendizajes.

La movilidad de la infografía es relevante, ante consumo móvil de colegiales y universitarios. Valero (2011) precisa que la infografía digital es texto-red con eficacia, independiente del medio. Para Cairo (2011), la infografía es un arte cuya esencia es la funcionalidad de la pieza. Y Marín (2009) señala necesidad de operatividad y adaptación a nuevos soportes tecnológicos, en función del movimiento (cinética), personalización y visualidad. 
Cada periódico analizado, se esfuerza por adaptarse a cambios tecnológicos y rediseños: El Tiempo digital "migró" algunas infografías a Responsive y El Tiempo impreso, sin micrositio web, adapta piezas solicitadas para digital. Aunque El País es Responsive, hay infografías en estado web original. Y en El Colombiano falta el concepto de movilidad. Por eso, infógrafos de El Tiempo y El País reconocieron la calidad de El Colombiano, pero recomiendan diseñar por bloques para Responsive. El País justifica bloques para adaptación y ajuste del software por seguridad, rendimiento, carga y visualización. Para profesionales de comunicación, lo Responsive es clave para interacción, accesibilidad, y multiplataformas, un regreso al diseño simple y liviano, mas no superficial.

Así como en el primer eje temático se resaltaban contenido y forma en infografía, este eje enfatiza la tecnología para que la información pueda ser recorrida, difundida, portable, compartida: circulación dentro y fuera de piezas; y multicanal.
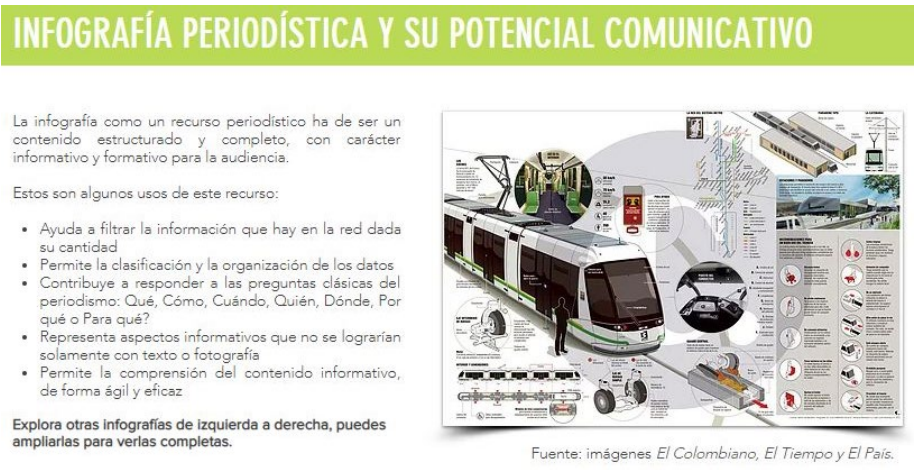

Imagen 6. Infografía periodística y potencial comunicativo. Propia. Infografía, prensa y formación escolar 
La mayoría de infógrafos consideraron que la formación de audiencia escolar no es misión del periódico, pero que, si contribuye, estará bien. Por ejemplo, El Tiempo define si la pieza informa, entretiene, explica, etc., y sus funciones. El País desarrolla narrativas neutras, globales y visuales para público internacional, aunque su premisa no sea educar; ve la infografía como contenido más visual y extenso que en redes, y como apoyo para profundizar. Para comunicadores y diseñadores, es clave que los infógrafos se pregunten qué pasa con usuario y pieza al comprender. Según la diseñadora visual y docente, Marcela Castaño, la infografía funciona como mapa mental y ha de ser bien realizada y comprensible, porque "La infografía está en la mente, no en el PC" (Entrevista personal, mayo 3 de 2017), y coincide con Madrid: "Internet dio posibilidad de pensar hipertextualmente, pero nosotros no lo plasmamos, y la infografía lo que hace es eso" (Entrevista personal, mayo 16 de 2017).

Pensando en primaria y secundaria, representantes de los tres medios, reconocen que la infografía es "un profesor dentro del periódico", por enganche, lectura rápida y multiplataforma, y que, si los docentes "pensaran infográficamente", lograrían que se "enamoren" de la infografía y se aproximen al periódico con otros hábitos de lectura y producción por potencial comunicativo (Imagen 6). Los entrevistados (comunicadores-periodistas, diseñadores) coincidieron en que la infografía facilita "pensar modularmente"; por ejemplo, el periodista y docente español Evaristo González destacó el alcance de la infografía asociado al efecto multimedia: otras formas de entendimiento con diferentes canales, los cuales ayudan al estudiante a generar una idea más real de los temas. (Entrevista personal, marzo 22 de 2017). En general, aunque los medios tienen entre sus funciones informar, entretener y educar, en la infografía de los tres periódicos está implícito el aporte educativo, en especial la sección "Materia" de El País ${ }^{7}$ sobre ciencia, tecnología, salud, etc. 
Entre tanto, las docentes confían en la prensa como medio, y creen en la infografía por veracidad, neutralidad informativa y contraste de voces con argumentos, ausente en redes. Resaltan que el periódico digital acerca al usuario a contenidos relacionados, ampliando el panorama para jóvenes. También, reconocen que los docentes pueden presentar infografías que generen interés, valoran la lectura y la producción infográfica con recursos web, búsqueda de fuentes, datos como filtro y despliegue temático visual. Validan el aporte en términos cognitivos, captura informativa, procesamiento, memoria visual y cultura general. Enfatizan que el trabajo en equipo al revisar infografías y producción, favorece aprendizaje colaborativo, inteligencias múltiples y competencias siglo XXI.

Tales competencias propuestas por entidades con proyectos mundiales, como el Assessment \& Teaching of 21st Century Skills (ATC21S), confirman la pertinencia infográfica en educación acorde a globalización, multiculturalidad y TIC. La ATC21S (s.f.) plantea diez competencias en cuatro categorías: conocimiento, habilidades, actitudes, valores y ética. Maneras de pensar: creatividad e innovación, pensamiento crítico, resolución de problemas y aprender a aprender. Herramientas para trabajar: manejo informativo y apropiación TIC. Maneras de trabajar: colaboración y comunicación. Maneras de vivir en el mundo: alusivas a la vida y la carrera, responsabilidad personal y social, y ciudadanía local y global. Esto supone que, para formar sin acumulación informativa y memorización, se vivencien seis principios de enseñanza y aprendizaje: aprender en colaboración con otros, aprender de acuerdo con necesidades e intereses propios, aprender haciendo, aprender con tecnología, conducir el propio aprendizaje, y renovar roles de docentes y estudiantes.

Para finalizar estos resultados, la infografía acerca a estudiantes a la prensa e introduce la educación en ella, y si los infografistas aprovechan, logran eficacia e impacto comunicativo (Imagen 7). En general, la infografía implica 
objetividad, investigación, multimodalidad y globalización, y por eso, diseñamos el sitio web.

Ahora puedes conocer herramientas y recomendaciones para iniciar la elaboración de las infografias. Además, en Colombia y en países de Latinoamérica hay cursos de manera presencial o virtuales para aprender más.

\section{HERRAMIENTAS RECOMENDADAS}

GENERACIÓN DE NARRATIVAS VISUALES Y VISUALIZACIÓN

$\begin{array}{ll}\begin{array}{l}\text { A PERIODIC TABLE OF VISUALIZATION METHODS } \\ \text { ver sitio }\end{array} & \begin{array}{l}\text { THE } 10 \text { COMMANDMENTS OF VISUAL } \\ \text { COMMUNICATION } \\ \text { ver sitio }\end{array} \\ \begin{array}{l}\text { CATÁLÓGO DE VISUALIZACIÓN DE DATOS } \\ \text { ver sitio }\end{array} & \begin{array}{l}\text { INFOGRAPHICS PROCESS } \\ \text { ver sitio }\end{array}\end{array}$

EL MUNDO ANÁLOGO ADQUIERE VIDA EN EL DIGITAL PARA REALIZAR INFOGRAFIAS

UN BILBAÍNO EN NATIONAL GEOGRAPHIC ver sitio

ALGUNOS USOS EDUCATIVOS DE INFOGRAFÍA
ASI SE HACE UNA INFOGRAFIA EN NATIONAL GEOGRAPHIC ver sitio

CONSEJOS PERIODÍSTICOS -INFOGRAFÍAS ver sitio

HEMEROTECA WEB: EL PAISS DE LOS ESTUDIANTES

Imagen 7. Herramientas recomendadas para infografía. Propia. Infografía, prensa y formación escolar 


\section{Conclusiones}

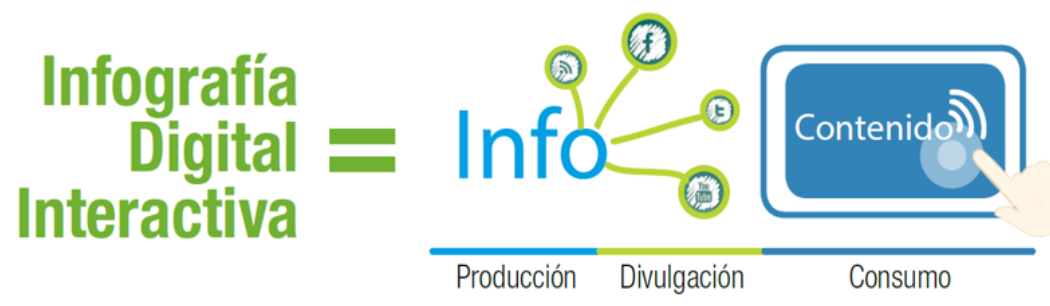

Imagen 8. Uso y apropiación infográfica. Propia. Infografía, prensa y formación escolar

Se agrupan por áreas temáticas:

\section{Infografía en educación y prensa escolar}

Hay un carácter pedagógico de la infografía, combinando diagramas visuales con lo textual y potenciando comprensión con lenguajes complementarios; enlaces entre información, lectura dinámica y múltiples niveles. Adicionalmente, como género se interesa por la audiencia en cuanto a claridad, eficacia en transferencia informativa y construcción de saberes (Imagen 8).

Para las docentes, la infografía no es solo recurso periodístico para prensa escolar, sino un medio útil en educación:

- Orienta al usuario al "mapear o escanear visualmente" un contenido, y motiva a explorar información asociada; de ahí, su alcance educativo para diferentes aprendizajes.

- Es recurso narrativo, comunicativo y divulgativo próximo a los jóvenes bajo aprendizaje móvil, porque el proceso que antecede a la lectura "habitual", es revisión de imágenes, previo a ejercicio mental amplio; y porque consumen información concreta y ágil. 
- Es en sí una elaboración estructurada, completa, que articula textos, ilustraciones, estadísticas y otras graficaciones. Por ello, tiene potencial para documentación, análisis y comprensión informativa técnica, científica, académica, etc.

- Brinda desarrollos cognitivos necesarios en entornos hiperconectados: autoaprendizaje, análisis, planeación y organización, para que numerosos datos recibidos adquieran forma estructurada y significativa desde el aprendizaje social, y no para exámenes específicos.

- Posibilita conductas responsables con principios éticos, y no tanto estéticos guiados por el periodismo: claridad, veracidad, precisión y manejo informativo con sentido social, al educar en comunicación. La búsqueda de instituciones indicó que requieren apoyo desde las secretarías de educación, pero a la vez, autonomía para producción propia.

- Para aplicación infográfica en prensa escolar, es fundamental que secretarías y prensa escuela la incluyan en su oferta formativa, junto a otras narrativas y contenidos educativos digitales.

- Ante dificultades para producciones impresas, las instituciones podrían enfocarse en medios digitales e infografía, para mayor uso y apropiación, múltiples alfabetizaciones e interacción.

- Más allá del equipo líder, la prensa escolar requiere similares recursos tecnológicos, humanos y dedicación no solo "extracurricular" o voluntaria.

- La infografía puede vincularse a educación superior en diferentes profesiones. Para básica y media, necesita integración de áreas, además de español y tecnología, o la del docente (s) líder del periódico.

\section{Infografía: producción, gestión y divulgación}

- Hay flexibilidad frente a distintos formatos, a funcionar con autonomía o colaborativamente y ser visual sin prioridad estética. Como género incluye aspectos de contenido, formales y de divulgación, pensando en la 
audiencia y en un sitio propio entre géneros tradicionales y, con ello, su nicho particular para acceder directamente al usuario.

- Facilita acceso informativo (exposición) e interrelación (exploración), para incrementar análisis, opinión, argumentación y creación de contenido. Así, para infógrafos, su reto no es simplificar y sintetizar información; sino que el usuario pueda quedarse ante la pieza, interrogándola y explorándola. Deben determinar qué tan complejo o profundo es un infográfico para el usuario, esfuerzo cognitivo, y capas o niveles informativos, porque una pieza puede resultar compleja y superficial a la vez: grande, densa, abstracta, saturada; implicar mucho tiempo de revisión, gráficos poco comunes o novedad y permitir poca comprensión. En oposición a otra simple, pero profunda al facilitar comprensión y apropiación: justo equilibrio.

- En infografía es fundamental actualización tecnológica, para que la audiencia circule a través de la información, y hacer que ella circule en web, otro aspecto del dinamismo infográfico, pues entre sus retos está mayor difusión con TIC.

\section{Otras investigaciones}

- La infografía periodística, no limita su uso, es referente para que docentes consulten piezas en fuentes académicas, científicas y estatales, ONG, empresas, portales educativos, etc, abriendo caminos a otros estudios.

- La literatura especializada convoca a promover entre académicos, investigaciones sobre TIC y narrativas digitales, para acercamiento mediático crítico y propositivo, como consumidores-creadores, con jóvenes y otras audiencias.

- Son recomendables investigaciones en infografía, comprensión y alfabetización visual en educación en diferentes públicos, para alcanzar otras perspectivas del problema investigativo. 


\section{Referencias}

Abreu, C. (2002). Periodismo Iconográfico (y XI): ¿Es la infografía un género periodístico? Revista Latina de Comunicación Social, (52). Recuperado de http://www.revistalatinacs.org/2002abreujunio5101.htm

Aguirre, C., Menjívar, E. y Morales, H. (2015). Elaboración de infografías: hacia el desarrollo de competencias del siglo XXI. Diá-Logos, 15 (9), 23-37. http:// dx.doi.org/10.5377/dialogos.v0i15.2207

Aigneren, M. (2002): La técnica de recolección de información mediante los grupos focales. Revista La sociología en sus escenarios, Centro de Estudios de Opinión, Universidad de Antioquia (6), 1-32. Recuperado de https://aprendeenlinea.udea.edu.co/revistas/index.php/ceo/article/ view/1611/1264

Bárcenas, M. (2012). La infografía periodística o la visualización de la información. Derecho a comunicar, (6), 22-42. Recuperado de http:// ccdoc. iteso. $\mathrm{mx} /$ cat.aspx?cmn=browse $\& \mathrm{id}=6479$

Cairo, A. (2008). Infografía 2.0: visualización interactiva de información en prensa. Madrid: Alamut.

Cairo, A. (2011). El arte funcional: infografía y visualización de la información. Madrid: Alamut.

Castrillo, G. (2009). El rol de la prensa en la educación. En E. Said Hung (Ed.), La educación como escenario de oportunidades para el desarrollo de Barranquilla (pp. 60-69). Barranquilla: Universidad del Norte. Recuperado de http://dialnet.unirioja.es/servlet/libro?codigo=532850

Ceballos, J.C. (2015). Medios de comunicación escolar, educación y ciudadanía (Tesis doctoral). Universidad Nacional de la Plata, Argentina. doi: https:// dx.doi.org/10.35537/10915/47712 
Churches, A. (2008). Taxonomía de Bloom para la era digital. Eduteka Eduteka.icesi.edu.co. Recuperado de http://eduteka.icesi.edu.co/articulos/ TaxonomiaBloomDigital

Colle, R. (2004, julio-diciembre). Infografía: Tipologías. Revista Latina de Comunicación Social, 7 (58), 1-19. Recuperado de https://www. researchgate.net/publication/26527147_Infografia_tipologias

Díaz, J. (2006). La interactividad y el periodismo on-line: una aproximación teórica al estado de la cuestión. Diálogos Possíveis, 5 (2). Recuperado de http://fba.unlp.edu.ar/lenguajemm/?wpfb_dl=61

Fondevila, J.F. (2014). El uso de hipertexto, multimedia e interactividad en periodismo digital: propuesta metodológica de ranking de calidad. Zer, 19 (36), 55-76. Recuperado de http://www.ehu.eus/ojs/index.php/Zer/article/ view/13488

García, D. (2014). Los infográficos periodísticos como género informativo. Historia y Comunicación Social, (19, Núm. Especial Febrero), 93-106. http://dx.doi.org/10.5209/rev_HICS.2014.v19.45013

González, E. (2016). La necesidad de educar en comunicación digital en la sociedad global. Linhas. Florianópolis, 17 (33), 8-28. https://doi.org/10.596 5/19847238173320163008

Hernández, R., Fernández, C. y Baptista, P. (2014). Metodología de la Investigación. México: McGraw Hill.

Íñiguez, L. (2008) Métodos cualitativos de investigación en Ciencias sociales [extractos] en Psicología Social. Recuperado de http://colombofrances. edu.co/wp-content/uploads/2013/07/metodos_cualitativos2.pdf

Leturia, E. (1998). ¿Qué es infografía? Revista Latina de Comunicación Social, 4. Recuperado de http://www.revistalatinacs.org/z8/r4el.htm 
Marín, B. (2009). La infografía digital, una nueva forma de comunicación (TDX - Tesis Doctorals en Xarxa). Universidad Autònoma de Barcelona. Recuperado de http://www.tdx.cat/handle/10803/48653

Minervini, M. (2005). La infografía como recurso didáctico. Revista Latina de Comunicación Social, 8(59), 1-11. Recuperado de https://www.redalyc. org/pdf/819/81985906.pdf

Reinhardt, N. (2008). Infografía Didáctica: Producción interdisciplinaria de infografías para la diversidad cultural. Cuaderno 31. Centro de Estudios en Diseño y Comunicación, (31), 119-191. Recuperado de http://www. palermo.edu/dyc/maestria_diseno/pdf/tesis.completas/10 Reinhardt.pdf

Rincón, O. (2016). La infografía educativa como herramienta didáctica. Una posibilidad de mediación del proceso formativo en el área de educación física de los estudiantes del grado décimo y undécimo de la Institución Educativa Federico Ángel del municipio de Caldas-Antioquia (tesis de maestría). Universidad Pontificia Bolivariana, Medellín. Recuperado de https://repository.upb.edu.co/handle/20.500.11912/2780

Rost, A. (2006). La interactividad en el periódico digital (tesis doctoral). Universidad Autónoma de Barcelona. Recuperado de http://www.tdx.cat/ bitstream/handle/10803/4189/ar1de1.pdf

Salaverría, R. y Cores, R. (2005). Géneros periodísticos en los cibermedios hispanos. En Salaverría, R. (coord.) Cibermedios. El impacto de internet en los medios de comunicación en España (pp. 145-185).

Strauss, A. y Corbin, J. (2002). Bases de la investigación cualitativa. Técnicas y procedimientos para desarrollar la teoría fundamentada. Medellín: Universidad de Antioquia, Facultad de Enfermería.

Trespalacios, D. (2015). Análisis de uso de infografías y plataformas de visualización de datos en la comunicación política colombiana entre 2010 
y 2014 (tesis de maestría). Universidad Pontificia Bolivariana, Medellín. Recuperado de https://repository.upb.edu.co/handle/20.500.11912/2641

Valero, J.L. (1999). La infografía en la prensa diaria española (tesis doctoral). Universidad Autónoma de Barcelona. Recuperado de https://joseluisvalero. files.wordpress.com/2013/01/tesis-de-josc3ba-luis-valero.pdf

Valero, J.L. (2010). La infografía periodística y documental impresa. Recuperado de http://incom.uab.cat/portalcom/wp-content/uploads/2020/01/58_esp. pdf

Valero, J.L. (2011). Algunas consideraciones sobre la infografía digital. Portal de la Comunicación Incom: UAB. Recuperado de http://www. portalcomunicacion.com/uploads/pdf/58_esp.pdf

Vargas, P., Greiff, A. y Rojas, O. (2014). ¿Infografía... visualización... diseño de información? En busca de los indicios de su configuración y delimitación como campo disciplinar. Kepes, 11 (10), 105-141. Recuperado de http:// vip.ucaldas.edu.co/kepes/downloads/Revista10_7.pdf

Wilson, C., Grizzle, A., Tuazon, R., Akyempong, K., and Cheung, C. (2011). Alfabetización Mediática e informacional. Currículum para profesores. UNESCO. Recuperado de http://unesdoc.unesco.org/ images/0021/002160/216099S.pdf 